\title{
Architecture as a Tool for Community Building in Two Different Islamic Cultures: Case of Masjid Pathok Negoro and Külliye
}

\author{
Mario Lodeweik Lionar ${ }^{1}$, Tülin Vural Arslan ${ }^{2}$, Selen Durak ${ }^{3}$
}

\begin{abstract}
Masjid pathok negoro is a particular type of mosque found in Yogyakarta, Indonesia; while külliye is a type of Islamic building complex established in the Ottoman Period of Bursa in Anatolia (modern Turkey). Both of them are neighbourhood-scaled architectures which were built not only for religious purpose but also to develop the social environment around them.

This paper aims to compare and to analyse the similarities as well as the differences between masjid pathok negoros in Yogyakarta, Indonesia, and the külliyes in Bursa, Turkey. Both can be considered as architectures which act as tools for community building in each of their cultures. The main difference is that the külliyes were used for the creation of new settlements in Ottoman Period of Bursa, while masjid pathok negoros were used for the enhancement of the already-established settlements in the Sultanate of Yogyakarta.
\end{abstract}

Keywords: masjid pathok negoro; külliye; Yogyakarta; Bursa; community building

\section{Introduction}

One of the various ways in which religious communities all over the world leave their trace is their built environments. It is evident that some of the most important architectures in the world are religious buildings. Acropolis in Greece, Cathedral of St. Peter in Rome, Al-Haram Mosque at Mecca; such are the examples of grand-scale religious architecture. Yet, as Kostof (1992) mentioned it, although the importance of these magnificent religious architecture works cannot be denied, it is often the smaller, more modest religious structures that in fact are the real gears of the society around them, which are the relevant actors in the urbanism. While at one extreme the personal, domestic shrine acts as the most private religious built environment and at the other the great, national-scale religious architecture act as the most grandeur, between them exist neighbourhood-scale religious structures which strengthen and unite the community around them. Kostof mentioned two kinds of such neighbourhood-scale religious architecture: one of them is Christian parish, and the other is Islamic neighbourhood community.

In these Islamic neighbourhood communities, mosque is undoubtedly the most important part. As Kostof mentioned, while the great Friday mosque unarguably is considered officially as the most important mosque of the community as a whole (usually 
at the scale of a city), it is the smaller, modest district mosques that form a kind of affiliation in the nearest surroundings. Although this common theme of mosque as a centre remains relatively the same, various Islamic cultures around the world have their own variations of architectural structure which depend on their geographical and cultural peculiarity. Moreover, at some Islamic region, the architecture goes beyond the mosque, forming a kind of complexes or structures consisted of various uses. Nevertheless, despite their different forms, these Islamic architectures maintain their roles as centre of society. Among these various form of Islamic religious architectures acting as centres of society at the considerably modest urban scale, two of them are külliye in Ottoman cities and masjid pathok negoro in Yogyakarta, Java, Indonesia.

Külliye is an architectural and urban form widely spread in Turkey and commonly associated with the Ottoman era. In short, külliye is a religious and social institution, physically built as a complex comprising of several buildings of various functions, with a mosque as its centre. Although many of them can be found at Istanbul, the kïlliye originated at Bursa, the first capital of Ottoman Imperium. Indeed, this unique architectural typology has a very influential role on the Ottomanization: built at five locations relatively far from Bursa old citadel, these sultanate külliyes encourage growth of new settlements around them, and in turn, these urban growth spread in an evenly distributed manner all over the city. Thus, the külliye can be considered as a kind of catalyst for urbanisation at the Ottoman Period of Bursa in Anatolia.

Masjid pathok negoro, on the other hand, is an architectural form found only in the Province of Yogyakarta Special Region, Indonesia. Masjid pathok negoro is an architectural formation comprising of five mosques, built at five locations evenly distributed at the outer side of ancient Yogyakarta Sultanate. These mosques were built for two main objectives: First, by being placed at the yet scarcely populated areas, they were meant to announce the sovereignty of the newly born Sultanate, thus symbolically keeping those vulnerable areas from both internal and external threats. Second, by using the mosques instead of forts or other military structures, the Sultanate meant to strengthen the understanding about Islam at those areas. Although each of five masjid pathok negoros is only consisted of a mosque, not a complex including any form of physical school, the teaching and coaching of Islam were conducted at these mosques. In turn, step by step a kind of Islamic settlements were formed around these mosques.

Thus, it can be considered that these two architectural forms share similar characteristics. By presenting Islamic structure - the mosque - as the center, both külliye and masjid pathok negoro can be considered as having similar architectural features. By being located at the regions distributed evenly far from the center of both cities, they can be considered geographically similar. There is even a hint that both of them share the similar role of symbolically defending the city, considering that masjid pathok negoros were indeed built intentionally at the outer border of Yogyakarta Sultanate and that two külliyes in Bursa were built at the outmost West and East border. Finally, if we consider the similar manner of how the settlements around them grew and been developed, it can be also considered as a similarity in terms of their urban role. It can be considered that both the külliyes and masjid pathok negoros are the architectural tools for community building. Community building can be defined as the practices directed toward the creation or enhancement of community within a regional area. Indeed, this is precisely the context 
of külliyes and masjid pathok negoros. Beside being known as the center for Islamic education in Bursa, the külliyes are considered also as the phsyical centers for the development of new settlements in the new-born capital; hence, the creation of new communities. As for the masjid pathok negoros, beside being known as the centers of Islamic education and spreading in the Sultanate of Yogyakarta, they also possess significant roles in strengthening the sense of already-established community and organizing the social life in which they were built; hence, the enhancement of the established community. Therefore, it will be significant to analyze these similarities in a more systematic manner, and to investigate the possibility of a similarity of their roles as tools for community building each of their specific cultural context.

\section{Brief history of külliye and its role on urbanisation in Ottoman Period of Bursa}

Architecturally, külliye can be described as a complex consisted of various functions: a mosque (cami), medrese (theological school), mekteb (school), imaret (kitchen soup), darüssifa (hospital), tabhane (guest room), hamam (bath house) and perhaps other functions required according to specific locations and patrons such as han (inn) or kervansaray - the cervanserais. Indeed, the name külliye itself means 'the whole' or 'collectivity' (Kostof, 1992). Kostof also mentioned that, from the broader point of view, kïlliye can be viewed as an institution combining social, cultural, and religious considerations. The first Ottoman külliye is the one conceptualized and established by Orhan Gazi in the 14th century at Bursa, the first capital of Ottoman Imperium. Albeit the simplicity of the elements, Orhan Gazi's külliye inspired the other successive Ottoman sultans to continue building other külliye, and later also several influential individuals other than the sultans, too.

The main reason for Orhan Gazi's successors to continue the tradition of building külliye is that the külliye possesses an important role in the urbanization, particularly at the beginning of the Ottoman era in Bursa. At the early times after the conquest of Bursa (1326), there was a need to develop the areas outside the Old Citadel, which then became the center of the Sultanate. This development was conducted by constructing the first sultanate kïlliye outside the walls of the Citadel, but still in a relatively close distance. The establishment of Orhan Gazi külliye (1339-1340) was proven successful in encouraging the development of new settlement around it.

After Sultan Murat I (also known as Hüdavendigar) took the succession, he built other kïlliye (1363-1389) at the West far end of Bursa, followed by Sultan Beyazit I (also known as Y1ldırım) who built his own külliye at the East far end (1391-1395), totally the opposite. Although there is no explicit proof, these acts of Sultan Murat I and Sultan Beyazit I are very likely a kind of strategy for declaring the sovereignty of the Sultanate at the outmost (and, therefore, the most vulnerable) areas. Two other successors built their külliyes between those previous two: Sultan Mehmet I (also known as Celebi) built his külliye (1411-1422) which then became commonly known as Yeşil Külliye between Orhan and Yildırım kë̈lliye, while Sultan Murat II built his own, known as Muradiye Külliyesi (1424-1426) and located between the Old Citadel and the külliye of Hüdavendigar (Table 1, Figure 1, and Figure 2). 


\section{Brief history of masjid pathok negoro and its role as the center of Islamic development in the Sultanate of Yogyakarta, Indonesia}

Islam made its debut in Indonesia as early as 12 th century, through the coming of the Muslim merchants by the sea voyage, and reached the Island of Java at about the 15th century. The merchants arrived at the large trading cities at the Northern coastal areas of the island (Abu Su'ud, 2003). The first Islamic sultanate in Java was established at this Northern Coastal of Central Java, predicted at 1475 or 1500: The Sultanate of Demak. The Sultanate of Demak reigned until 1550. While two more Islamic Sultanates also existed at West Java - Banten (1524-1813) and Cirebon (1552-1677) - it is the Sultanate of Pajang at Central Java (1568-1618) which can be considered as a direct successor of Demak. From this Sultanate of Pajang born the Sultanate of Mataram (1586-1755), whose territory encompassed the nowadays Central Java, the Province of Yogyakarta, and several areas of East Java and West Java - in short, this is a legendary Javanese Islamic Sultanate.

Table 1. The sultanate külliyes in Bursa

\begin{tabular}{llll}
\hline Külliye & Year & Sultan & Location \\
\hline Orhan Külliyesi & $1339-1340$ & Orhan Gazi & $\begin{array}{l}\text { out of/beside } \\
\text { the Old Citadel of Bursa }\end{array}$ \\
\hline $\begin{array}{l}\text { Hüdavendigar } \\
\text { Külliyesi }\end{array}$ & $1363-1389$ & Murat I & $\begin{array}{l}\text { far West end of Bursa, } \\
\text { north of Çekirge }\end{array}$ \\
\hline Yildırım Külliyesi & $1391-1395$ & Beyazıt I & far East end of Bursa \\
\hline Yeşil Külliye & $1411-1422$ & Mehmet I & $\begin{array}{l}\text { Yetween Orhan Bey Külliyesi and } \\
\text { Yildrım Külliyesi }\end{array}$ \\
\hline Muradiye Külliyesi & $1424-1426$ & Murat II & $\begin{array}{l}\text { between the Citadel and } \\
\text { Hüdavendigar Külliyesi }\end{array}$ \\
\hline
\end{tabular}



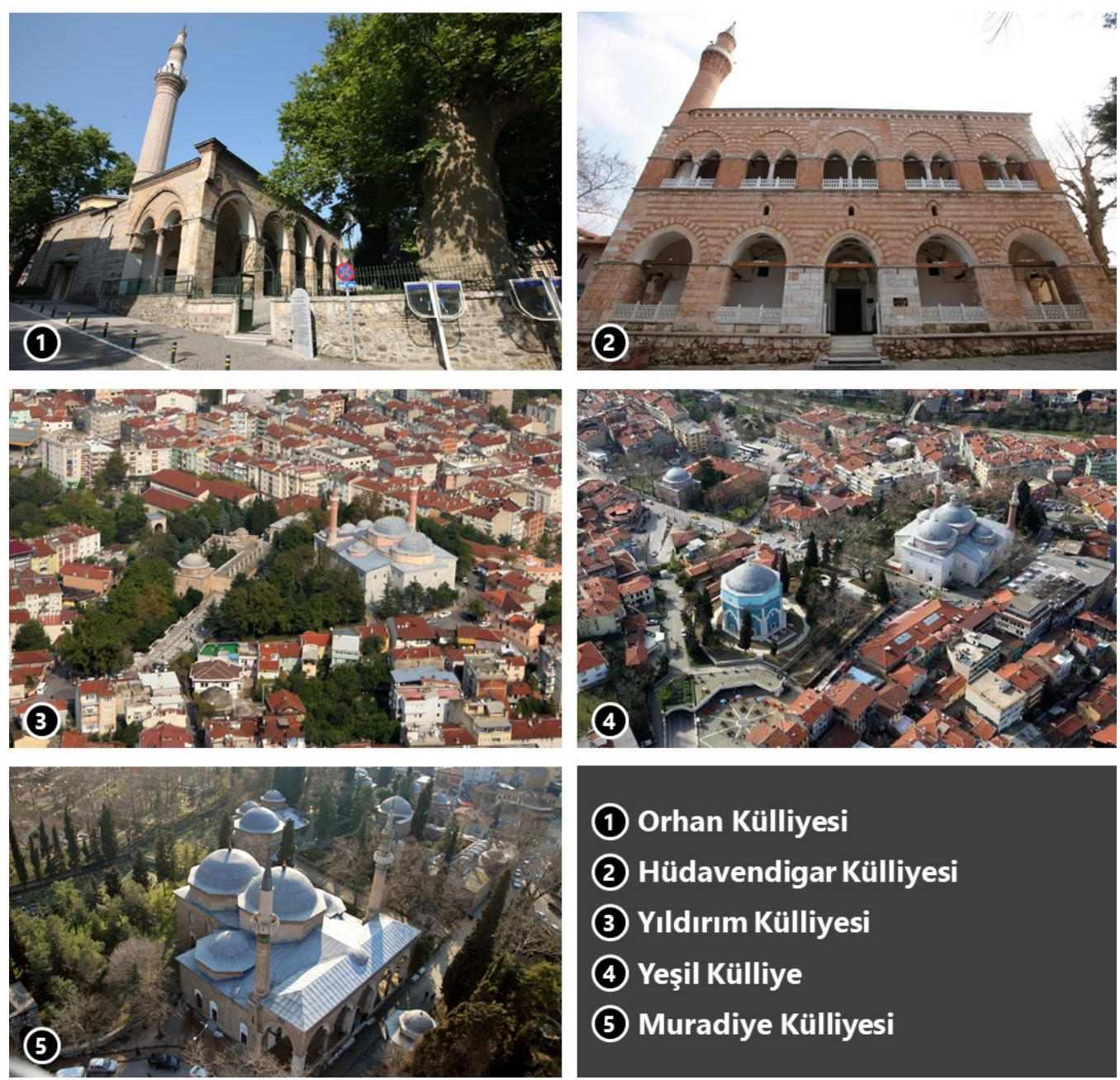

(1) Orhan Külliyesi

(2) Hüdavendigar Külliyesi

(3) Yıldırım Külliyesi

(4) Yeşil Külliye

(5) Muradiye Külliyesi

Figure 1. Five sultanate külliyes in Bursa (source: http:/ / alanbaskanligi.bursa.bel.tr/fotograf-arsivi/) 

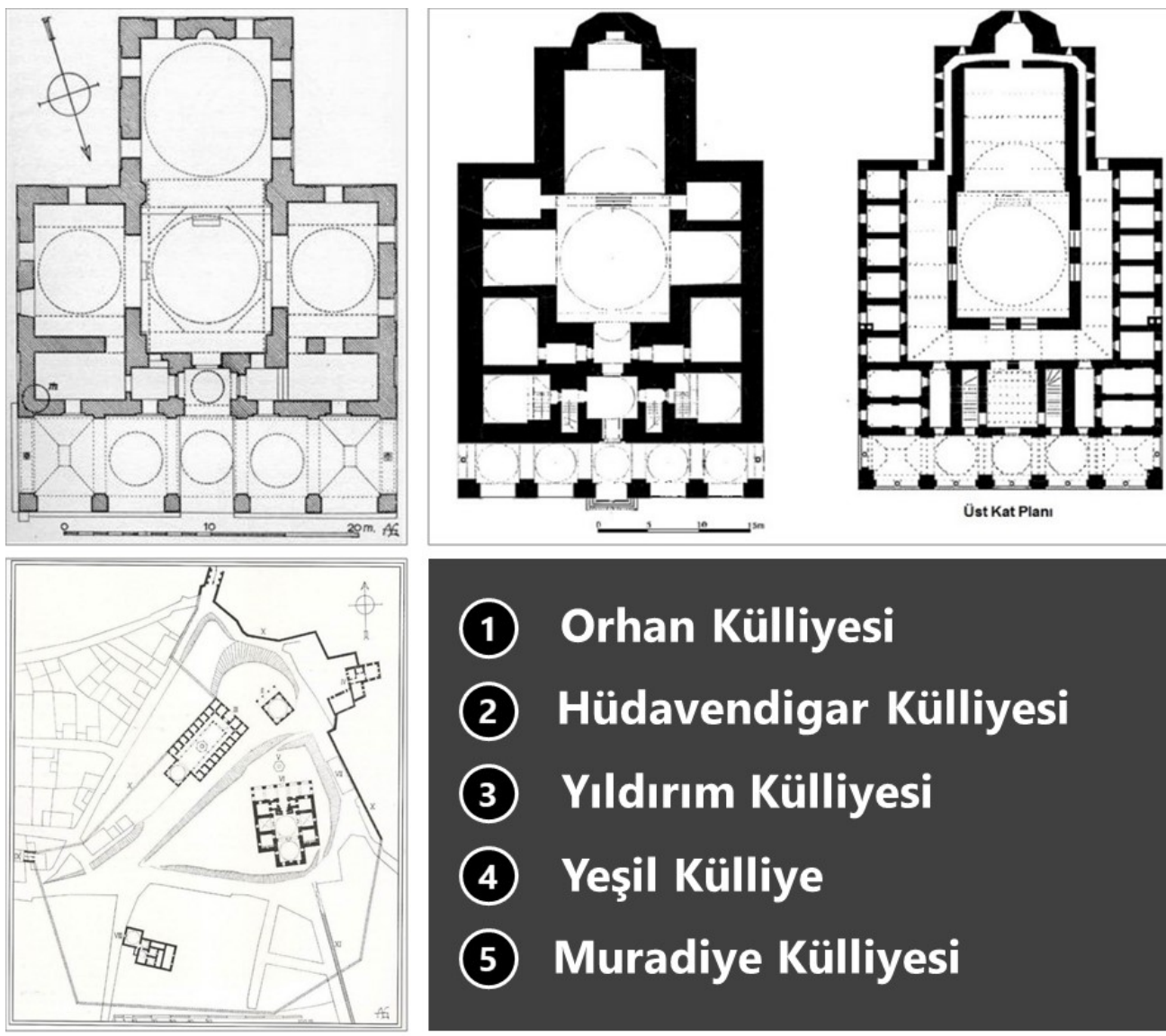
(1) Orhan Külliyesi
(2) Hüdavendigar Külliyesi
(3) Yıldırım Külliyesi
(4) Yeşil Külliye
(5) Muradiye Külliyesi
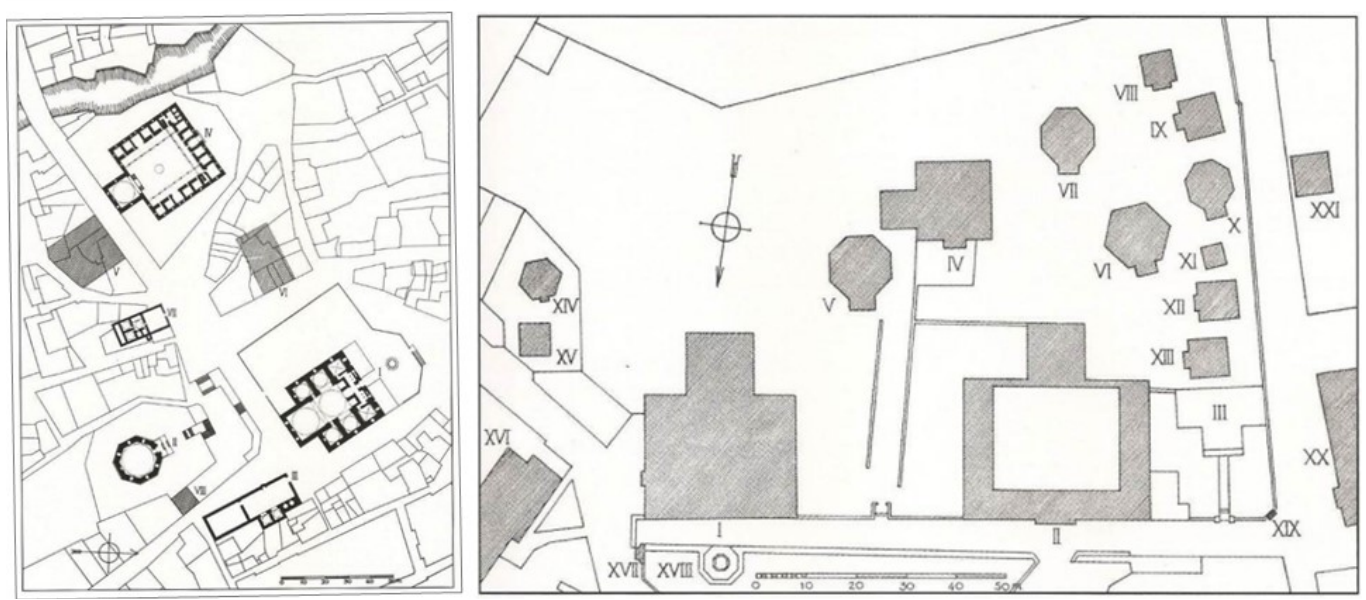

Figure 2. Floor plans and site plans of five sultanate külliyes in Bursa (source: Gabriel, 1958) 
The Sultanate of Mataram was split into two due to the internal conflict and intervention of Dutch Colonialist by means of The Pact of Giyanti at 1755. The Sultanate was split into the Sultanate of Surakarta at the nowadays Solo (Surakarta), Province of Central Java, and the Sultanate of Yogyakarta at the nowaday Yogyakarta, Province of the Special Area of Yogyakarta (Mastingah, 2010). Both of them still exist so far. Masjid pathok negoros were conceptualized and physically realized at the reign of this Islamic Sultanate of Yogyakarta.

So far, the term masjid is used all-over Indonesia and generally means 'mosque'; a structure which is built for a publicly communal prayer. By definition, pathok (Javanese language) means literally 'stake' or 'peg'. In Javanese context, pathok is a piece of wood or bamboo used for marking land border, signifying the ownership and dominion of the possessor (Culture Boards of Yogyakarta \& UGM, 2006). However, the term pathok also has a more metaphorical meaning: it can also be translated as rules, laws, and canons (Rahmawati, 2014), especially when the word pathok is transformed into another form: pathok-an. By definition only, negoro or nagari means 'nation', 'sultanate', or 'government'. Yet, in the context of the term pathok negoro and masjid pathok negoro, the term negoro specifically refers to the city at which the Sultan govern, which means the city of Yogyakarta. After the term pathok and negoro were combined into new term pathok negoro, it refers to two meanings: the first is the area along the border of the city of Yogyakarta. The second meaning refers to the title and role given to a person: based on a judgement that this very person is sufficient enough in terms of religious/Islamic, spiritual and managerial capabilities, he then was given a duty to be an extension of the Sultan, in a context that he had to govern the people inhabiting the area at which he was placed.

The term masjid pathok negoro, thus, refers to five specific mosques built at the outer border of Sultanate of Yogyakarta. They were meant as symbolic security posts and centre of Islamic education. The persons chosen as pathok negoro were placed at these mosques, given the duty as imam (a kind of priest) and responsible for teaching and spreading Islam as well as managing the problems and, in general, managing the social lives at the settlements around these mosques. The actual initiator of masjid pathok negoro is Kyai Muhammad Faqih, husband of the older sister of the wife of Sultan Hamengku Buwono I: he is the brother-in-law as well as the spiritual and religious mentor of the first Sultan (Wardatun, 2001). It was Kyai Muhammad Faqih that proposed the concept of masjid pathok negoro to the Sultan, stressing the importance of the presence of spiritual and social guidance at the outmost geographical border of the sultanate. Following this proposal from Kyai Muhammad Faqih, he was appointed as the chief of the other pathok negoros. A piece of perdikan land (a land freed from the duty of tax), located at the south of the village at which he lived, was given to him. A humble mosque was built at this land in 1774 (Wardatun, 2001), in the reign of Sultan Hamengku Buwono I. It was given a name Wonokromo. This humble mosque was not meant as a finished masjid pathok negoro itself; it was more a trial, a prototype for the concept.

In 1760, an old mosque located at the village of Mlangi (at the West border area of Yogyakarta), which originally built at 1724 (the reign of the Kartasura Sultanate, the predecessor of Yogyakarta Sultanate), was renovated by Sultan Hamengku Buwono I and re-established as masjid pathok negoro, and was given a name Jami Nur (Utomo, 2015). Similar with Jami Nur Mosque, an old mosque located at the village of Plosokuning (at 
the North border area of Yogyakarta) which originally built in 1724 (Prasetyo, 2016) also re-established as masjid pathok negoro after the concept was formulated, and was given the name Sulthoni. This North mosque later was rebuilt and removed to the north of the original site during the reign of Sultan Hamengku Buwono III, 1810-1811 and 18131814. The reason of this rebuilding was apparently for the mosque having the architectural characteristic similar to the central Masjid Gedhe/Grand Imperial Mosque located near the Palace; as for the replacement, no valid reason can be found yet. It is the only masjid pathok negoro which retains its original appearance since its rebuilding. In 1774, the third masjid pathok negoro was established at the village of Babadan, East border area of Yogyakarta, and given the name Ad-Darojat. In 1775, the next masjid pathok negoro was established at the village of Dongkelan, South border area of Yogyakarta, and given the name Nurul Huda. The fifth masjid pathok negoro was finally built in 1819, during the reign of Sultan Hamengku Buwono IV (1814-1823), at Wonokromo, and given the name Taqwa (Table 2, Figure 3, and Figure 4).

Table 2. Masjid pathok negoros in Sultanate of Yogyakarta

\begin{tabular}{|c|c|c|c|}
\hline $\begin{array}{l}\text { Masjid } \\
\text { Pathok Negoro }\end{array}$ & Year & Sultan & Location \\
\hline Jami Nur & 1724,1760 & HB I & Mlangi, West border area \\
\hline Sulthoni & $\begin{array}{l}1724, \\
1810-1814\end{array}$ & $\begin{array}{l}\text { HB I, } \\
\text { HB III }\end{array}$ & Plosokuning, North border area \\
\hline Ad-Darojat & 1774 & HB I & Babadan, East border area \\
\hline Nurul Huda & 1775 & HB I & Dongkelan, South border area \\
\hline Taqwa & 1819 & HB IV & Wonokromo \\
\hline
\end{tabular}



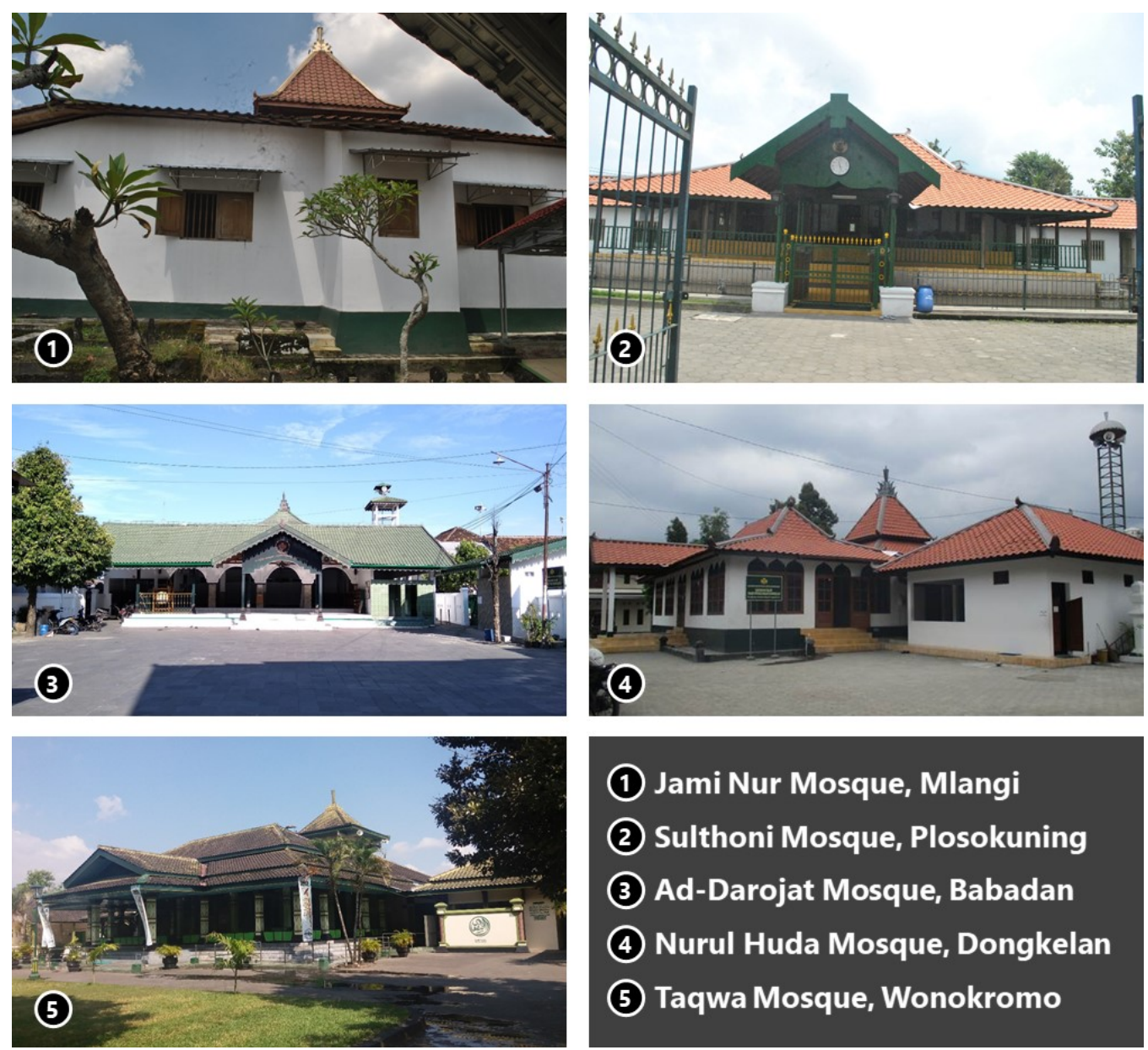

Figure 3. Five masjid pathok negoros in Yogyakarta (source: Trieddiantoro, 2018)

\section{Comparative analysis between külliye and masjid pathok negoro}

In order to analyse the similarities as well as the differences between the külliye and masjid pathok negoro in a more detailed and systematic manner, the comparative analysis will be conducted according to four aspects on which the general similarities as well as detailed differences between these two structures are most distinctly identifiable: geographical, political, religious, and social aspects. 

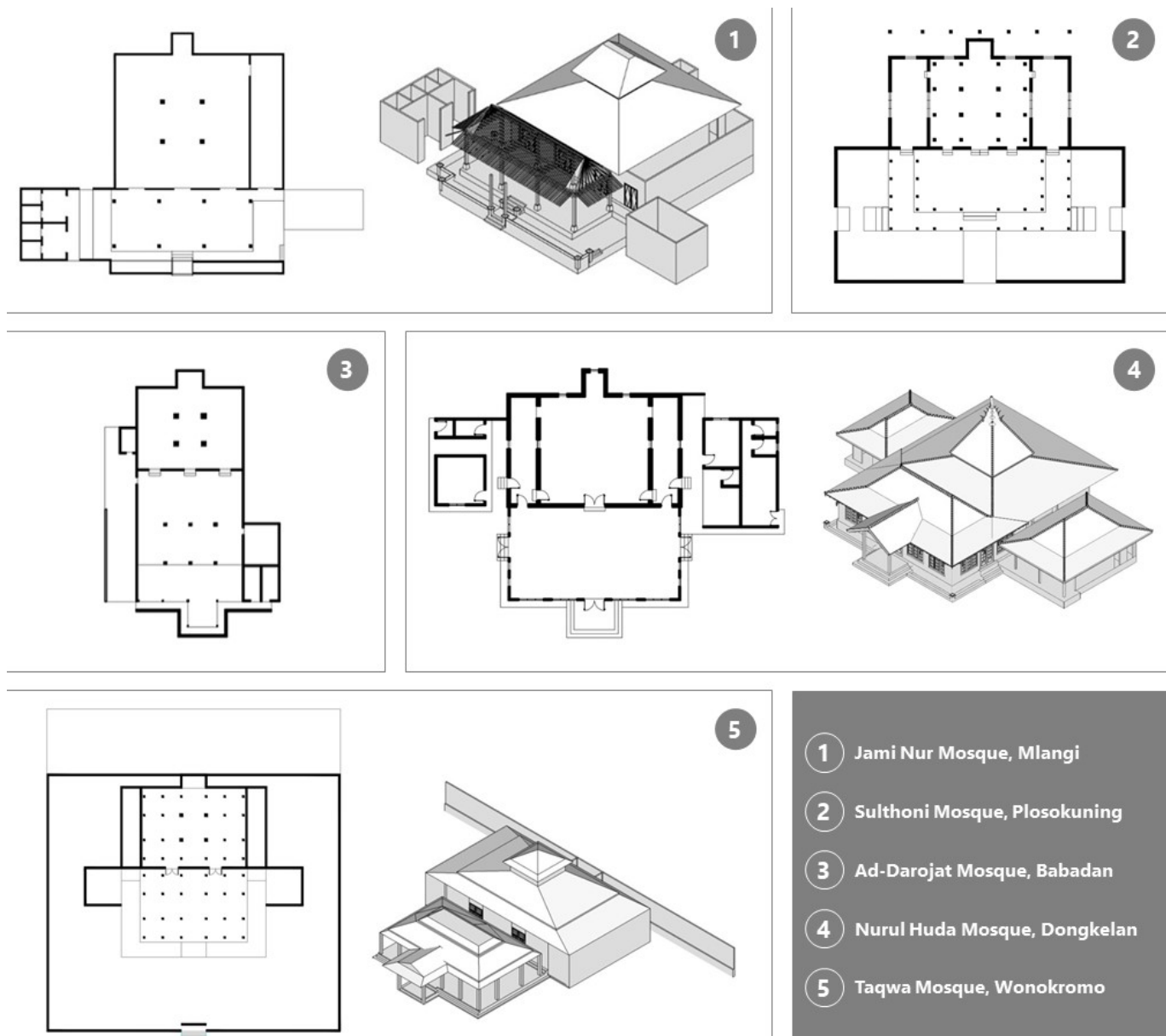

5

Figure 4. Floor plans and site plans of five masjid pathok negoros in Yogyakarta (source: Trieddiantoro, 2018)

\subsection{Geographical comparison}

The common physical characteristic most evidently identifiable in the kïlliye and masjid pathok negoro is their remote locations. It is become evident, however, that remoteness is not the only common characteristic. The manner in which sultanate külliye are more-or-less evenly distributed all over the territory of Bursa is somewhat similar to the manner masjid pathok negoro are located, surrounding the area of the Sultanate of Yogyakarta.

With the exception of the first kïlliye built by Orhan Gazi, which is located outside but close to the Old Citadel (hisar) of Bursa, all the sultanate kïlliyes were built far from the Citadel. Two kiulliyes which were built directly after Orhan's are the most remote: Hüdavendigar Külliyesi is located about $3 \mathrm{~km}$ to the West of the Citadel, while Yildırım Külliyesi is located about $2 \mathrm{~km}$ to the East of the Citadel. Meanwhile, Yeşil Külliye was built more or less at the same distance both from Orhan Külliyesi and Yıldırım Külliyesi, while Muradiye Külliyesi was built more or less at the midpoint between Hüdavendigar 
Külliyesi and Orhan Külliyesi. In short, these five sultanate külliyes are placed in a somewhat linear formation from the West to the East end of Bursa and are spaced relatively evenly (Figure 5).

Similar to the kïlliyes, masjid pathok negoros were built at several areas remotely located from the old sultanate centre. While the sultanate kiulliye of Bursa are ordered in a linear manner with the Old Citadel of Bursa being a point located along the line, four masjid pathok negoros which were built earlier were placed in a rather circular manner (Figure 6), forming an imaginary circle or rectangle encircling the old sultanate centre which is located at the centre. Four mosques which were built earlier were placed at the four points of compass respectively: Sulthoni Mosque at the North, Jami Nur Mosque at the West, Nurul Huda at the South, and Ad-Darojat at the East, with the fifth mosque, Taqwa, was built later at the South.

This similar placement evidently indicates a similar concept: both the külliyes and masjid pathok negoros are architectural forms holding the role to mark the geographical border of both the Bursa and the Sultanate of Yogyakarta. By being distributed evenly in a linear manner throughout the territory, the five sultanate kïlliyes can be interpreted as an act to determine the boundary of the city of Bursa (UNESCO, 2014). However, there is no evidence that this interpretation indeed was intended as such. On the other hand, one of the objectives of the establishment of masjid pathok negoros, indeed, is to mark the geographical boundary of the Sultanate of Yogyakarta (Sumardjo, 2002). Yet, it should be noted that the border appears to be more symbolic and spiritual in characteristic rather than physical: what is more important here is not the actual territory borderline of Yogyakarta Sultanate, but rather is the concept of four points of compass; or, in the own words of Javanese culture, the concept of moncopat and moncolimo.

Moncopat is a combined word consisted of monco (a Javanese term means 'difference') and papat (a Javanese term means 'four'). Literally moncopat can be translated as 'four differences'; substantially it is about the division of space (at any scale) into four divisions, each of them represents different elements of life and manifests certain meanings. At cosmic scale, these four divisions are represented by four points of compass (North-South-East-West directions). Moncolimo is a combined word consisted of monco (a Javanese term means 'difference') and limo (a Javanese term means 'five'). It is basically a perfection of moncopat. The four elements, four divisions, four points, found in moncopat are repeated again with the addition of the fifth central point located at the very centre of other four points. This fifth central point represents the ultimate harmony, the most sacred, and therefore is on the higher degree than the other four. Thus, moncolimo is considerably the most perfect and highest Javanese cosmological-spatial concept (Tjahjono, 1989).

Together with Masjid Gedhe (Grand Mosque) which is located at the old sultanate centre, four masjid pathok negoros which were built earlier indeed are the physical, architectural manifestation of the Moncopat-Moncolimo cosmological concept (Hardiyatno, 2015). These four masjid pathok negoros are placed at the outmost border of the city, distributed at the four points of compass, representing the four divisions of space and universe (Figure 7). At the centre, there exists Masjid Gedhe, the greatest sultanate mosque at the time (since masjid pathok negoros are also counted as sultanate mosques). It 
is evident that the geographical placement of these mosques is according to a more symbolic rather than pragmatic or utilitarian consideration.

Thus, although the factual situations indicate the similar idea of distributing the structures evenly all over the territory (the külliye at Bursa and masjid pathok negoro at the Sultanate of Yogyakarta), there is a difference regarding the actual intention (Table 3). While masjid pathok negoros were intentionally placed as such according to certain concept - in this case, symbolic rather than utilitarian - there is no evidence about such intention on the külliye.

Table 3. Comparative analysis of sultanate külliyes at Bursa and masjid pathok negoros at Sultanate of Yogyakarta in terms of geographical aspect

\begin{tabular}{|c|c|c|}
\hline & & $\begin{array}{l}\text { Masjid Pathok } \\
\text { Negoro }\end{array}$ \\
\hline \multirow{3}{*}{$\begin{array}{l}\text { Geographic } \\
\text { border }\end{array}$} & \multirow[b]{2}{*}{ Similarity } & $\begin{array}{l}\text { The placement of both the complexes } \\
\text { indicates a concept of marking the } \\
\text { geographical borders of both cities by using } \\
\text { the architecture }\end{array}$ \\
\hline & & $\begin{array}{ll}\text { Two out of five } & \begin{array}{l}\text { Four out of five } \\
\text { masjid pathok negoros }\end{array} \\
\text { sultanate külliyes are } & \text { are placed at the } \\
\text { located at the most } & \text { outer side (the } \\
\text { end of Ottoman } & \begin{array}{l}\text { border area) of } \\
\text { sultanate Yogyakarta }\end{array} \\
\text { Bursa } & \end{array}$ \\
\hline & Difference & $\begin{array}{l}\text { No evidence on } \\
\text { whether there were The concept of } \\
\text { intentions or not geographic border is } \\
\text { regarding the officially intentional/ } \\
\begin{array}{l}\text { concept of planned } \\
\text { geographic border }\end{array}\end{array}$ \\
\hline
\end{tabular}




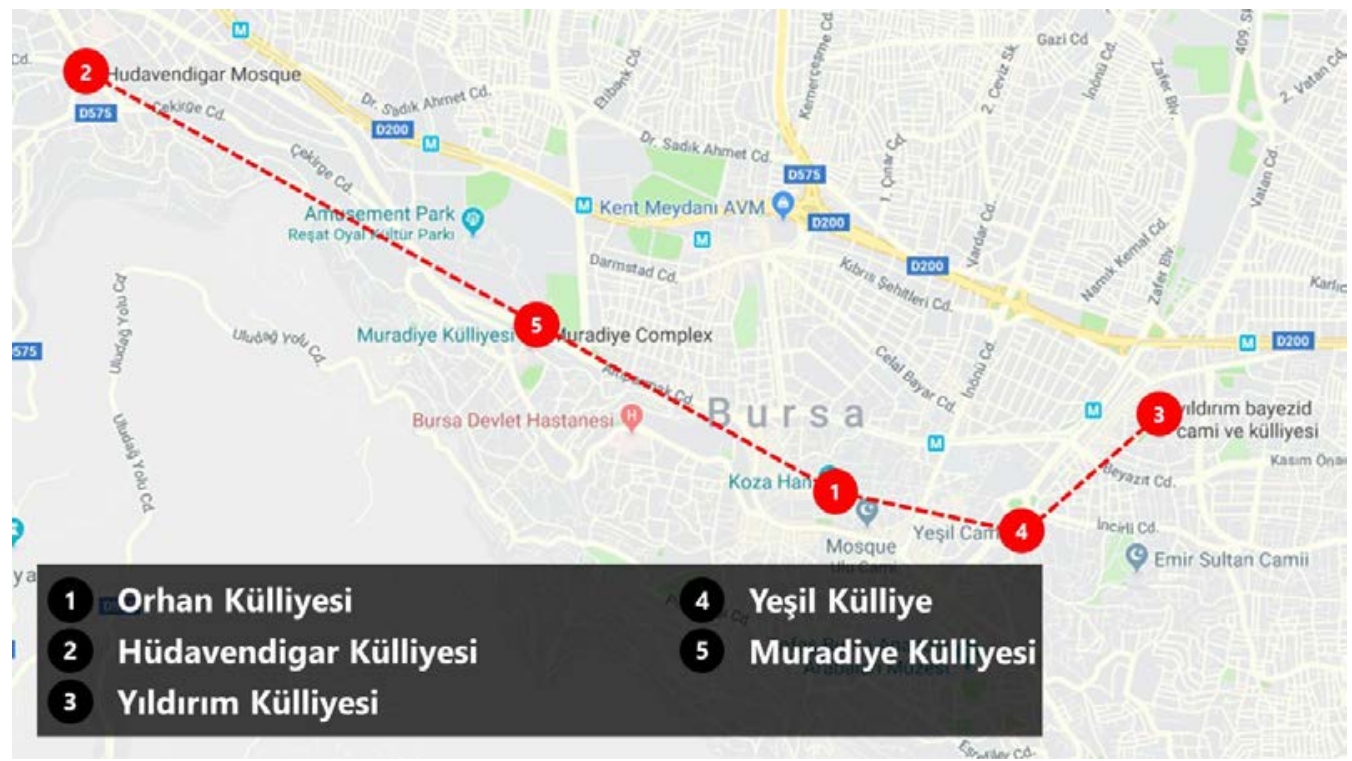

Figure 5. The linear formation of the sultanate külliyes in Bursa (2018, adapted from the Google Maps)

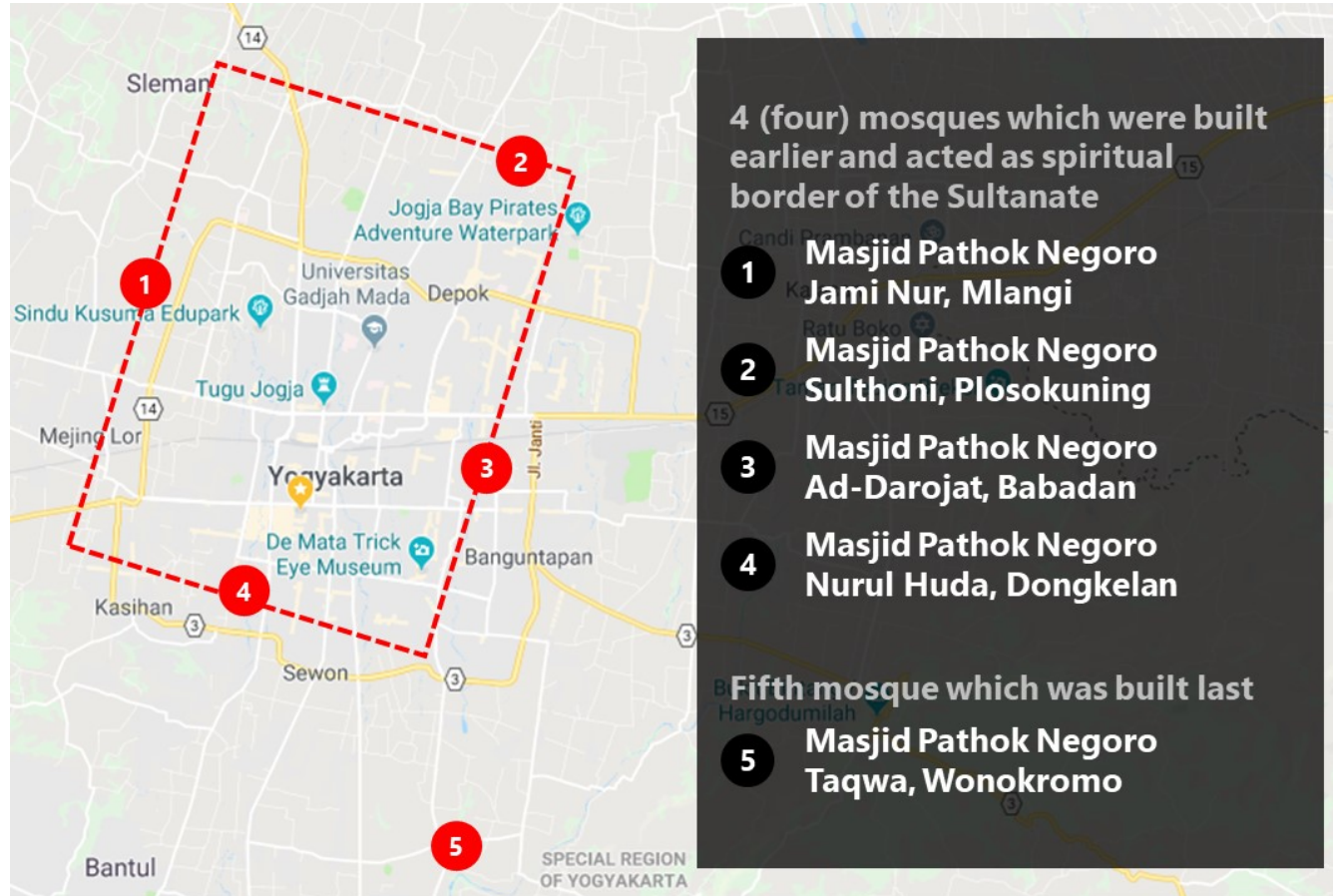

Figure 6. The circular formation of masjid pathok negoros in Yogyakarta (2018, adapted from the Google Map) 

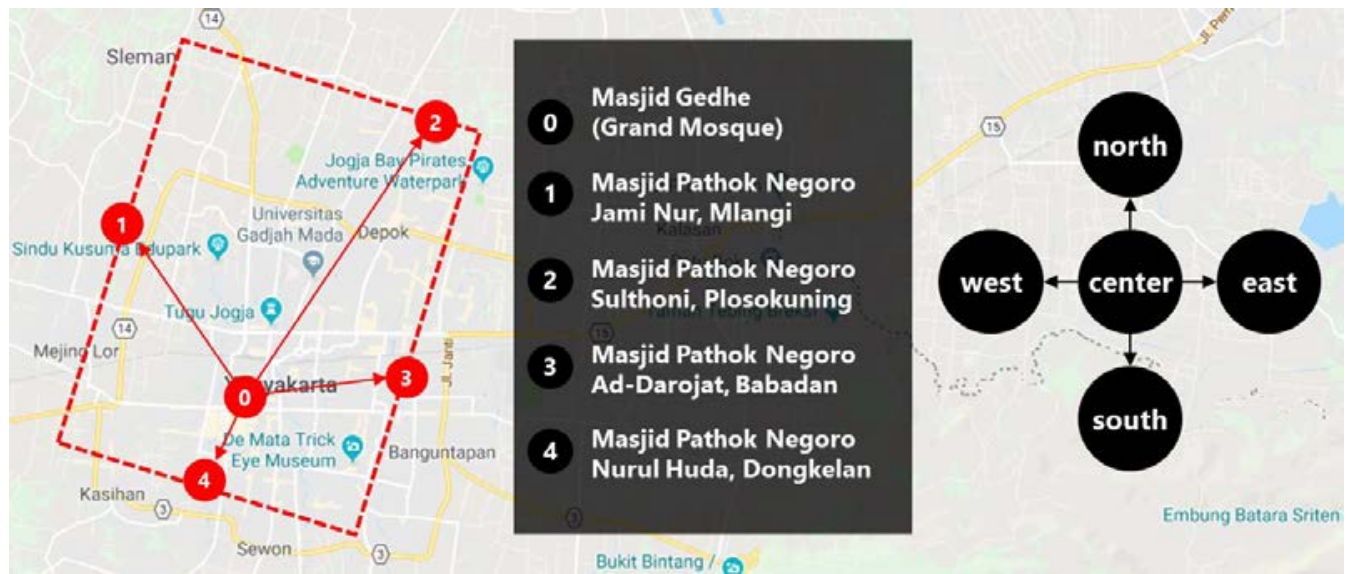

Figure 7. The concept of Moncopat-Moncolimo and its manifestation in site selection of four masjid pathok negoros and The Grand Mosque (2018, adapted from the Google Map)

\subsection{Political comparison}

Despite the absence of any evidence of the actual intentions on the concept of geographical border, the placement of the külliyes in Bursa indeed had political intentions. According to Pancaroğlu (1995), the külliyes were placed at such remote areas to mark those areas as the territory of the new-born Bursa. As a sultanate which keeps on expanding its territory continuously, it is important for the sultanate to state its dominion on new areas. This strategy is similar to the political consideration behind the site selections of masjid pathok negoros. By placing those mosques at locations far from the palace, the sultanate stated their dominions on those areas (Nafisyah and Rokhman, 2016). Setiabudi (2005) explained also that masjid pathok negoro is a specific typology of community masjid found only at Yogyakarta; no such typology can be found at other sultanates in Java.

However, the types of these territory-marking strategies are different. The külliyes, at least which were built earlier, were placed at the new areas due to the rapid expansion of the territory of Bursa. This idea can be perceived most clearly on Hüdavendigar Külliyesi and Yildırım Külliyesi, both of them are the külliyes located most remotely from the Old Citadel. The site selection strategy of masjid pathok negoros, on the other hand, is more about re-stating the territory of Sultanate of Yogyakarta and distinguishing it from the Sultanate of Surakarta, since both of them are two new sultanates formed by the splitting of Sultanate of Mataram.

Being remotely placed, there existed the efforts to connect both the külliyes and masjid pathok negoros to their old city centers respectively. Being placed at remote locations, it is important for both structures to ensure that the outsiders (i.e., people who are not Ottomans neither Javanese) understand clearly who possess those structures. At masjid pathok negoros, this idea was implemented by applying the similar architectural style used at Masjid Gedhe (Grand Mosque), the official largest sultanate mosque located at the old sultanate center (Pemberton, 2003, and Rahmawati, 2014).

The sultans who built külliyes used different method: at the same period they built the kïlliye at the area far from the Old Citadel, they also built another much simpler structure 
close to or inside the Old Citadel (Pancaroğlu, 1995). This method of building 'twin structures' was pioneered by Orhan Gazi who, beside constructing Orhan Külliyesi, also built a mosque inside the Old Citadel, his tomb (Orhan Bey Türbesi), and the Palace (Bey Saray1). His step was followed by Hüdavendigar who paired his këlliye with a simple mosque close to Bey Saray1, and by Y1lırım who paired his këlliye with the famous Grand Mosque. This very strategy pioneered by early sultans of Bursa was repeated by Fatih Sultan Mehmet (Mehmet II) when he built his famous Fatih Külliyesi paired with Topkap1 Sarayı, but interestingly Pancaroğlu didn't mention about what Mehmet I and Murat II built to pair their külliye. One acceptable reason for this is that the act of building 'twin structures' is, again, related to the act of expanding the territory and conquering new areas. Three earliest sultans of Bursa who applied the idea of 'twin structure' clearly are the sultans with the most impressive achievement in conquering and expanding the territory of Bursa, and Fatih Sultan Mehmet is clearly the Conqueror of Istanbul. Pancaroğlu did mention also, however, that the later külliye built in Istanbul were more about showing the dominion of the patrons and their contribution in developing the city rather than marking new territory; this statement probably can be applied too to Mehmet I and Murat II.

Thus, it can be concluded that the külliyes at Bursa and masjid pathok negoros at Sultanate of Yogyakarta share the similar political objective as the physical marker of the territory. Yet, while masjid pathok negoros are markers for the relatively static territory, külliyes are the markers for expanding territory and new areas (Table 4).

Table 4. Comparative analysis of sultanate külliyes at Bursa and masjid pathok negoros at Sultanate of Yogyakarta in terms of political strategies

\section{Külliye}

Masjid Pathok Negoro

\begin{tabular}{|c|c|c|c|}
\hline \multirow{2}{*}{$\begin{array}{l}\text { Political } \\
\text { consideration } \\
\text { in locating } \\
\text { the structures }\end{array}$} & Similarity & \multicolumn{2}{|c|}{$\begin{array}{l}\text { Both the külliyes and masjid pathok negoros are located far from the } \\
\text { city center to announce the sovereignty of the sultanates }\end{array}$} \\
\hline & Difference & $\begin{array}{l}\text { The külliyes were built to mark } \\
\text { new, expanding territories }\end{array}$ & $\begin{array}{l}\text { Masjid pathok negoros were built } \\
\text { to mark the already-established } \\
\text { territory, nor new neither } \\
\text { expanding territories }\end{array}$ \\
\hline \multirow[b]{2}{*}{$\begin{array}{l}\text { Relation with } \\
\text { the old } \\
\text { sultanate } \\
\text { center }\end{array}$} & Similarity & \multicolumn{2}{|c|}{$\begin{array}{l}\text { There were efforts made to establish relations between these } \\
\text { structures and the city center }\end{array}$} \\
\hline & Difference & $\begin{array}{l}\text { the concept of double-structure } \\
\text { (the remote yet elaborate külliye } \\
\text { and simple structure near the } \\
\text { Old Citadel) built at the period } \\
\text { of a sultan's governance }\end{array}$ & $\begin{array}{l}\text { The official instruction for } \\
\text { masjid pathok negoros to } \\
\text { architecturally resembling Masjid } \\
\text { Gedhe (Grand Mosque) located } \\
\text { at the old sultanate center, near } \\
\text { the Palace }\end{array}$ \\
\hline
\end{tabular}




\subsection{Religious comparison}

It should not be forgotten that both the kïlliye and masjid pathok negoro are indeed religious, Islam-influenced architecture. Masjid pathok negoro are mosques, while kïlliye are architectural complexes consisted of several various use - among them are imaret (soup kitchen), tabhane (guesthouse), hamam (bathhouse), and sebil (fountain) - yet, the center of the complexes are cami (mosques) and medrese (theological school). Such a specific use should be preceded by the existence of Islamic communities. Indeed, both kïlliyes and masjid pathok negoros were constructed to accommodate religious communities. Before the siege and conquer of Bursa, there existed settlements outside the Citadel which were consisted of various group of nomads (Oğuzoğlu, 2013). Among these group was a religious-social community called abilik ("brotherhood"). After Bursa was conquered, the first kïlliye was built as a religious complex equipped with accommodation functions, with the abilik as its main user in mind. By using the kiulliye as the architectural center of new community, abilik was meant to be its main agent for change. In other words, the kiulliye and abilik, were meant to act together to expand the life in Bursa. On the other hand, the conception of masjid pathok negoro was made according to the guidance of Kyai Muhammad Faqih, and the idea about a number of mosques as multiple nuclei for Islamic education was probably inspired by the organized Islamic education held by him and his students. Furthermore, Wonokromo Mosque, the prototype for masjid patbok negoro, was built particularly for Kyai Muhammad Faqih and therefore was designed according to his and his students' needs (Wardatun, 2001). In other words, it is a kind of religious scholar community.

Despite this similarity, there is a main difference between the manners in which (scholarly) religious activities took place. In general, in the context of the külliyes, religious activities mostly happened inside the complex. Part of this reason is that the formal education were held in the medrese buildings, which were situated inside the complex. Yet, the other reason is that the custom in Bursa to accommodate the traveling dervishes in the mosques located inside the kïlliyes. This custom gave way to a specific type of mosque known as 'Bursa-type'. This type of mosque usually is referred as the 'reversed-T plan' type mosque, or zaviyeli cami in Turkish. In this context, zaviye means 'dervish lodge': a room or rooms dedicated to accommodate those traveling dervishes (Boykov, 2013).

Without exception, all the five sultanate kïlliyes in Bursa are reversed-T plan type mosques. In this arrangement, the mosques are consisted of three major wings, arranged around the central space in the shape of a reversed letter-T (Figure 8). According to Boykov (2013), originally, only the single wing located farthest from the entrance which was intended as a space for congregational prayers. The other two wings were intended to more personal activities, such as individual prayers, Qur'an reading, doing zikr, or discussions. The central space, on the other hand, was intended as a kind of inner courtyard, and not a space for prayers. It is evident, for example, from the difference of the elevations. The wings are elevated about 1 meter from the central space and are accessed through series of steps. The presence of several 'niches' in the vertical side of the elevated congregational prayers wing, which is intended as spaces for worshippers to store their shoes before ascend to the wing, again emphasizes that, while the elevated wing was intended to be 'sacred', the central space certainly is not. This difference is 
further stated by the presence of the ablution fountain at the central space, which implies that the space is indeed a courtyard, albeit a closed one. However, nowadays all the four major parts of these mosques (three wings and one central part) are used for the congregational prayers.
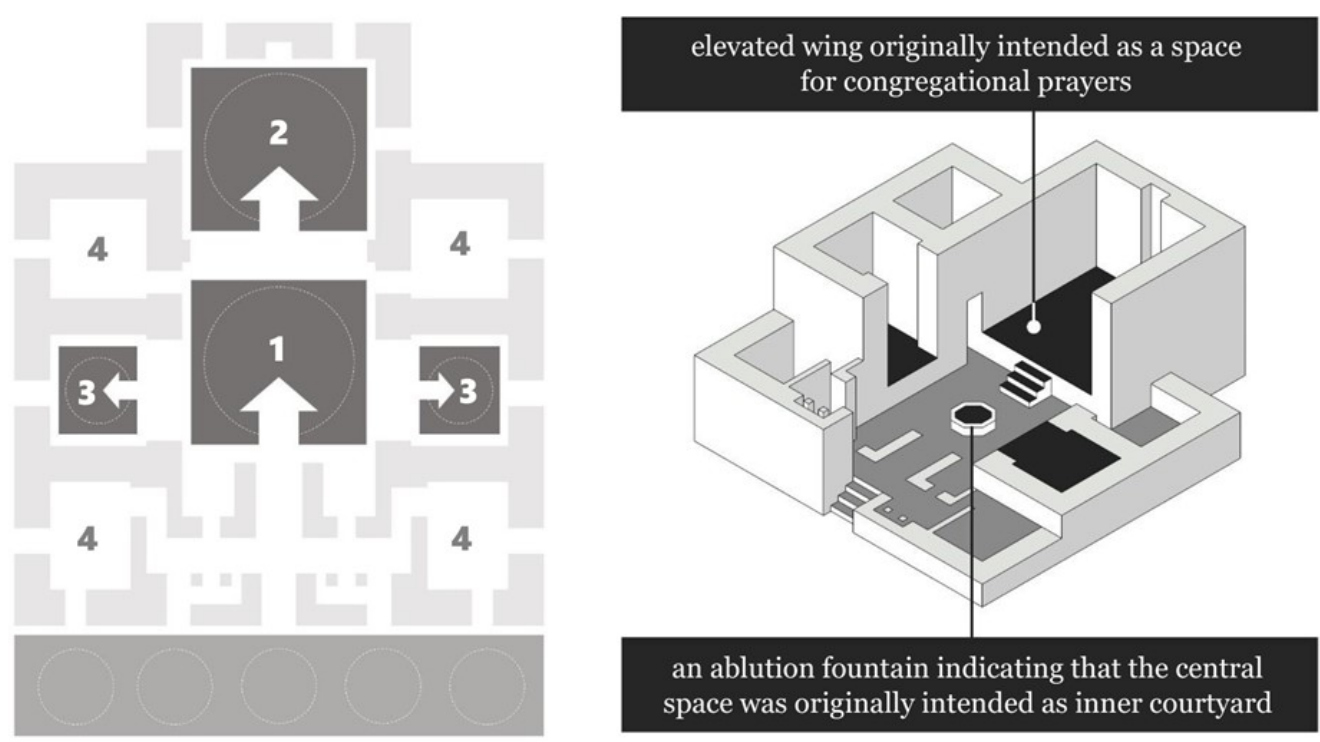

1. Central space, originally intended as an inner courtyard and not considered sacred

2. The wing originally intended as a space for congregational prayers

3. The side wings originally intended as spaces for personal prayers, reading, discussion etc.

4. Zaviye/tekke (lodges originally intended as accommodation spaces for travelers and dervishes)

Figure 8. Floor plan and axonometric section of Yeşil Mosque in Yeşil Külliye as example of reversed T-plan type mosques in Bursa (2018)

It is the rooms which are located at the corner of these reversed-T plan type mosques which are called zaviye or tekke, or 'dervish lodges'. These rooms were used as shelters for travelers in general and traveling dervishes in particular. It is very reasonable to visualize the dervishes who stayed at the külliyes were involved in discussions between themselves, with the students at the medreses, even with the worshippers from around the kïlliyes. It can be understood, then, that by offering the spaces for the accommodation for those dervishes, these revised T-plan type mosques indeed gave contribution to enliven the religious atmosphere in the külliyes.

There is no official record about the actual religious activities at the time masjid pathok negoros were built. However, there are some reports about how those mosques contribute on the growth of current religious activities around them. This is because masjid pathok negoros possess no building types specifically designed for the purpose of school activities, such as medrese in the külliyes. Therefore, in the context of masjid pathok negoros, Islamic educations were held not at at the mosques, and probably even at the houses outside the 
mosques. Thus, the Islamic teachings reached not only the disciples but also the nondisciple civilians, resulted in livelier religious life. Murti (2016) mentioned that Masjid Pathok Negoro Jami Nur at Mlangi (which is located at the West) greatly contributes by encouraging the establishment of several musholla (praying pavilion) and pesantren (theological school similar to Turkish medrese), each of them now acts as multiple centers for Islamic education. The intense activities trigger the forming of new centers, and those new centers trigger back the activities in such an iterative manner (Gumelar, 2016). Murti also mentioned that the Plosokuning area (the North) at which Masjid Pathok Negoro Sulthoni is located also experiences the similar lively religious life in a form of various and intense religious activities. These activities are similar to the religious ceremony which are held in the sultanate palace (Aulia, 2013) and began from the earlier era of Yogyakarta Sultanate. This implies that these activities was performed continuously since the time of the mosque's establishment.

There is no evidence regarding religious activities around masjid pathok negoro AdDarojat Babadan (the East one) and Nurul Huda Dongkelan (the South one); nowadays the activities around these two mosque has became less religious compared to the other two. The research by Yuli (2015) suggested that this may be the consequence of the construction of relatively-new ring road in Yogyakarta, which basically divide the city into the area inside and outside this ring road. Before this event, all four main masjid pathok negoros were considered as being on the outer periphery of the city or, in other words, in a way not a part of the city's main area. Yet after this construction, some of them considered as being on the inner part or, in other words, became the parts of the city's main area. Among the four masjid pathok negoros which are built earlier, only the North (Sulthoni at Plosokuning) and the West (Jami Nur at Mlangi) remain on the outer side of the new ring road; the South (Nurul Huda at Dongkelan) and the East (AdDarojat at Babadan) now considered as parts of the city. Interestingly, both the North and the West are in the condition closest to their original intentions. It explains the relatively vast number of researches conducted on both of them, while almost no research specifically conducted for the South and the East. Physically, among four of them, only the North retains its original form; the West, although experienced several redesigning, has been already restored closer to its original form. The South and the East already lost so much of their original components. In terms of religious activities, again only the North and the West can be considered dense with Islamic activities: at the North a pesantren (theological school) community can be found continuing; at the West a number of new mosques, pesantrens, and Islamic schools are blossoming. As for the East and South mosques, they serve regular prayers only, but there are not as many religious activities as can be found in the North and the West mosques.

Thus, it can be concluded that both the kïlliyes and masjid pathok negoros indeed contributed to the enhancement of religious activities in their areas in general, through the management of Islamic educations in both of them. The difference here is the way the educations were conducted. While formal Islamic educations in külliyes were held inside the complexes, in the specific building types (medrese), the Islamic educations in masjid pathok negoro were conducted in a more fluidly manner. Mosques still were the center, but the activities may take place outside the mosques. This point gave impact to another difference: while the religius scholar communities in Bursa are centered inside 
the külliyes, the activities in masjid pathok negoros encouraged the growth of another religious scholar communities outside the complexes (Table 5).

\subsection{Social comparison}

The most prominent and widely-known aspect of the külliye is that they were built mainly for the social purpose: as the centres of new settlements resulted from the continuously expanding territory of Bursa (UNESCO, 2013). Kuran (1968) stated that the külliye was built to provide services required for Muslim communities inhabiting the new neighbourhoods outside the Citadel of Bursa. The külliye implied in this statement is probably the Orhan Külliyesi, since the expression 'outside the citadel' or so implies location(s) not so far from the Citadel. As time went by, new dwellings were built, and the neighbourhoods grew. This is probably also the case with Hüdavendigar and Y1ldırım Külliyesi, which were built far from the Citadel. At such remote locations, the establishment of the külliye undoubtedly trigger the forming of new settlements.

Table 5. Comparative analysis of sultanate külliyes in Bursa and masjid pathok negoros in Sultanate of Yogyakarta in terms of religious activities

\section{Külliye}

Masjid Pathok Negoro

The first built examples of both the complexes were preceded (and possibly inspired) by the existence of religious communities targeted as the main 'user' of the complexes

\begin{tabular}{|c|c|c|c|}
\hline \multirow[t]{2}{*}{$\begin{array}{l}\text { Particular } \\
\text { religious } \\
\text { communities }\end{array}$} & Similarity & $\begin{array}{l}\text { Ahilik (brotherhood) was } \\
\text { existed before the first kiulliye } \\
\text { was established }\end{array}$ & $\begin{array}{l}\text { The Islamic community of Kyai } \\
\text { Muhammad Faqih and his } \\
\text { disciples was existed before the } \\
\text { conception of masjid pathok } \\
\text { negoro }\end{array}$ \\
\hline & Difference & $\begin{array}{l}\text { There are no direct evidence } \\
\text { about the külliye's effect on } \\
\text { encouraging the growth of } \\
\text { religious scholar community } \\
\text { outside the külliyes }\end{array}$ & $\begin{array}{l}\text { There are indirect evidences } \\
\text { that the establishment of masjid } \\
\text { pathok negoro encouraged the } \\
\text { growth of Islamic scholar } \\
\text { communities outside them }\end{array}$ \\
\hline \multirow[b]{2}{*}{$\begin{array}{l}\text { Religious } \\
\text { activities and } \\
\text { architecture }\end{array}$} & Similarity & \multicolumn{2}{|c|}{ Complexes acted as the center/focus of Islamic learning } \\
\hline & Difference & $\begin{array}{l}\text { Islamic education was } \\
\text { conducted in the specific } \\
\text { buildings (medrese/ theological } \\
\text { school) inside the complexes }\end{array}$ & $\begin{array}{l}\text { Islamic education was } \\
\text { conducted flexibly: in the } \\
\text { mosques and other structures } \\
\text { outside the complexes }\end{array}$ \\
\hline
\end{tabular}

Beside their religious role, masjid pathok negoro were established also with social consideration: beside providing spiritual guidance and religious jurisprudence for the society, the pathok negoros (the term 'pathok negoro' here refers to the title and role given to specific persons) also took responsibility to guide them socially, solving the communal 
problems not limited to the religious one (Rahmawati, 2014). Since this means that those pathok negoro (persons) are basically intended to be the central leader of the community, it should be expected that masjid pathok negoro (architecture) acted as the physical centre of the settlement. As in the case of their religious activities, there is no official evidence about the actual conditions at the time of the mosques' establishments; yet, there are some reports about the nowadays conditions. Murti (2016) and Gumelar (2014) mentioned about masjid pathok negoro Jami Nur at Mlangi (the West one) and Sulthoni at Plosokuning (the North one) being the centre for the wide range of social activities, not only religious one. The study on settlement pattern around these two mosques by Yuli (2015) also shows the high density of social activities, thus it can be deduced that such a density must be developed in a considerably long period, their beginnings traced back to the establishment of these mosques. Nafisyah and Rokhman (2016) particularly focused on Sulthoni Mosque at Plosokuning, concluding about the role of the mosque as a community centre and culture acculturation. It should be noted, however, that the research conducted by Nafisyah and Rokhman only covered the condition beginning at 1976, two centuries since the establishment of Sulthoni Mosque. Nevertheless, according to the observation, religious activities happened in the mosque retain their original characteristics. Therefore, it can be deduced that this mosque had already been a centre of such activities since its establishment. In short, the masjid pathok negoros can be considered a form of community social centre similar to the kïlliyes: both of them can be considered architectural tools for community building.

Community building can be defined as “... a process aimed at strengthening the capacity of individuals and organizations to develop and sustain conditions that support all aspects of community life", or more holistically as

“... continuous, self renewing efforts by residents and professionals to engage in collective action, aimed at problem solving and enrichment, that creates new or strengthened social networks, new capacities for group action and support, and new standards and expectations for the life of the community (Blackwell \& Colmenar, 2000)". This definition clearly describes community building as an act in terms of social works. Yet, in terms of architecture, it is evident, too, that "... apart from community members, the built environment is also a fundamental component of every community (Chansomsak \& Vale, 2009)", and that architecture posseess a huge potency to transform the community to the better conditions, given that the community give the chance to the architecture. In this context, it is precisely the case of how both kïlliye and masjid pathok negoro took roles in the transformations of their communities respectively.

However, there is a difference in the manner the kïlliye and masjid pathok negoro were used in terms of community building. It is clear that the settlements around the sultanate külliyes in Bursa were constructed were in a pioneering style: those are new settlements born in new areas as a result of continuously-expanding territory of Bursa. On the other hand, the areas at which masjid pathok negoros were constructed, albeit being remote from the old sultanate center, were not results of expanding territory; rather, they were the result of Mataram Sultanate's splitting into two new sultanates, the Sultanate of Yogyakarta and the Sultanate of Surakarta. Therefore, although these areas can be considered politically new, their characteristic is not similar to the pioneer areas found in Bursa. It is likely that masjid pathok negoros were built at several areas already populated; 
thus, the mosques are not the very first structures built on such areas. This estimation can be deduced from the official statement about masjid pathok negoro as constructed at tanah perdikan, or the lands freed from the duty of taxes. In turn, the inhabitants of these lands had to do some other special duties (Setiabudi, 2015). In the case of masjid pathok negoro, it is the duty to educate and to spread Islam. It means that there should be a community already settled before the conception and realization of masjid pathok negoros. The last major difference between külliye and masjid pathok negoro is about the economic aspect of them. It is widely known that the külliye also acts as an economic catalyst. One of the five sultanate külliyes in Bursa is considered as the city's commercial centre (UNESCO, 2017); no doubt that this mentioned külliye is Orhan Külliye. Beside socially related, this first sultanate külliye in Bursa was also economically related with the abilike brotherhood. By settling themselves around the külliye and forming a professional organization (İnalc1k, 2014), this brotherhood performed the main economic activities. Thus, the külliye can be considered as an indirect catalyst of Bursa's economic development. Yet, to be able to sustain themselves, the külliyes must have their own financial source. This financial source is the vakuf system, which was used in the Ottoman era as a financial source for the mosques and medrese/theological schools (Gürbüz, 2012). The sultanate külliyes at Bursa were also financially maintained by this system. Thus, the vakuf system cannot be separated from the külliye.

Meanwhile, there is no such evidence about the economical aspect of masjid pathok negoro. There was no such system as vakur in Yogyakarta; since masjid pathok negoro are considered sultanate mosques, and since the pathok negoro themselves - the persons in charge to manage those mosques - were directly appointed by the Sultan, it can be deduced that the financial source of masjid pathok negoro is probably the tax collected by the Sultanate. However, the areas at which masjid pathok negoro were constructed were freed from the tax. Similarly, there is no information about how the communities of masjid pathok negoro made their living. Murti (2016) did mention in her research that the nowadays community of pesantren (medrese/theological school) at masjid pathok negoro Mlangi earn their livings from making crafts, but no notions about any economic aspect at the time the mosque was constructed. This lack of documentary has been noticed by Graaf and Pigeaud (1985), who mentioned that there is very few (almost none) historical records about the economic conditions in ancient Java.

In short, while the sultanate külliyes in Bursa are structures intended to encourage the growth of new settlements, masjid pathok negoros are structures intended to strengthen and direct the already-established settlement. It is actually described clearly in the definition proposed by Blackwell and Colmenar (2000) mentioned previously; that community building is an effort both to "... create new" and to "strengthen" the already-established community. Thus, the külliyes are more about creating new communities while masjid pathok negoros are more about enhancing and strengthening the established communities (Table 6). 
Table 6. Comparative analysis of sultanate külliyes in Bursa and masjid pathok negoros in Sultanate of Yogyakarta in terms of their social aspect

\section{Külliye}

\section{Masjid Pathok Negoro}

Both the külliye and masjid pathok negoro were intended as an Social intention Similarity architecture acting as the physical center of social encouragement for the settlements around them

\begin{tabular}{|c|c|c|c|}
\hline $\begin{array}{l}\text { Type of } \\
\text { encouragement }\end{array}$ & Difference & $\begin{array}{l}\text { The kïlliye were intended to } \\
\text { encourage the growth of new } \\
\text { settlements }\end{array}$ & $\begin{array}{l}\text { Masjid pathok negoro were } \\
\text { intended to strengthen and direct } \\
\text { the already established } \\
\text { settlements }\end{array}$ \\
\hline Social aspects & Difference & $\begin{array}{l}\text { The kïlliye held role in general } \\
\text { aspect of urbanism and social } \\
\text { life: both the idealistic aspects } \\
\text { such as religion and } \\
\text { spirituality, and the more } \\
\text { pragmatic aspects such as } \\
\text { economy and trading }\end{array}$ & $\begin{array}{l}\text { Masjid pathok negoro were } \\
\text { intended particulary as } \\
\text { guidances in terms of religious } \\
\text { and social-cultural aspect, but no } \\
\text { evidence of their economic } \\
\text { aspect }\end{array}$ \\
\hline
\end{tabular}

\section{Conclusion}

As structures built with considerably bold religious characteristic, despite several differences between the külliyes and masjid pathok negoros (which are understandable regarding their different geographical, historical, and cultural contexts), both külliye and masjid pathok negoro can be considered similar in several aspects. Beside their similar religious intentions - to be centres of Islamic education and Islamic communities - the külliye and masjid pathok negoro also share the similar geographical aspect (the architectural manifestation of territory border) and similar political aspect (structures being built to state the dominion of both the sultanates). Finally, both the structures also share the similarity in term of social aspect: both the külliye and masjid pathok negoro were also intended to be social catalysts for the communities and societies around them, and it is apparent that both of them can be considered successful in performing such role. In other words: both the külliyes and masjid pathok negoros can be considered as architectures which possess significant roles in terms of community building in each of their cultural context. The main difference here is that the külliyes were used specifically to create new settlements, while masjid pathok negoros were used more to enhance the settlements which were settled previously.

This study is about the description of the conditions of the külliyes and masjid pathok negoros as well as a comparative analyses between those two structures. Further studies can be conducted to analyse the causative aspects of the similarities and the differences, as well as expanding the scope of the study to compare these two structures with similar features found in other Islamic cities. 


\section{References}

Abu Su'ud. 2013. Islamologi : Sejarah, Ajaran dan Perannya dalam Peradaban Umat Manusia (Islamology: History, Teaching, and Its Roles in Human Civilization). Jakarta: Rineka Cipta.

Aulia, R. 2013. Makna Simbolik Arsitektur Masjid Pathok Negoro Sulthoni Plosokuning Yogyakarta (The Symbolic Meanings of the Architecture of Masjid Pathok Negoro Sulthoni Plosokuning Yogyakarta). Yogyakarta: Universitas Islam Negeri Sunan Kalijaga Yogyakarta.

Blackwell, A. , \& Colmenar, R. 2000. Community-building: From local wisdom to public policy. Public Health Reports, 115, p.161-166.

Bokyof, G. 2013. Mastering the Conquered Space: Resurrection of Urban Life in Ottoman Upper Thrace (14t - 17th C.). Ankara: İhsan Doğramacı Bilkent University.

Bursa Metropolitan Municipality Bursa Site Management Unit. 2014. accessed on May 8th 2018 from http://alanbaskanligi.bursa.bel.tr/fotograf-arsivi/

Chansomsak, S. \& Vale, B. 2009. The Roles of Architects in Sustainable Community Development. Journal of Architectural/Planning Research and Studies, Volume 6, Issue 3, 2009. p. 109-136.

de Graaf, H., \& Pigeaud, T. 1985. Kerajaan-Kerajaan Islam di Jawa: Kajian Sejarah Politik Abad ke-15 dan 16 (Islamic Sultanates in Java: The Analysis of Political History in 15th and 16th Centuries). Jakarta: Grafiti Press.

Gabriel, A. 1958. Bir Türk Başkenti Bursa (Bursa, a Turk Capital). İstanbul: Seçil Offset.

Gumelar, M. A. 2016. Pengaruh Kegiatan Keagamaan pada Pola Ruang Kawasan Pathok Negoro Mlangi Yogyakarta (The Impacts of Religious Activities on the Spatial Patterns at the Area of Pathok Negoro Mlangi Yogyakarta). Yogyakarta: Universitas Gadjah Mada.

Gürbüz, V.M. 2012. Ottoman Vakifs: Their Impact on Ottoman Society and Ottoman Land Regime. Ç.Ü. Sosyal Bilimler Enstitüsü Dergisi 21, Say1 1., 201-212.

Hardiyatno, S. 2000. Simbol-simbol pada Masjid Kerajaan Jawa : Studi Makna Simbolik Ungkapan Fisik dan Setting Bangunan pada Kasus Masjid-mesjid Kerajaan di Surakarta dan Yogyakarta (Symbols on Javanese Sultanates' Mosques: A Study on Symbolic Meanings of Physical Expressions and Building Settings on the Case of Sultanate Mosques in Surakarta and Yogyakarta). Yogyakarta: Universitas Gadjah Mada.

İnalcık, H. 2014. Kuruluştan Tanzimat'a Bursa'da Sanayi ve Ticaret. Prusia'dan Bursa'ya (From Prusia to Bursa) (p. 111-171). Istanbul: Yap1 Kredi Yayınlar1.

Kostof, S. 1992. The City Assembled: The Elements of Urban Form Through History. London: Thames \& Hudson.

Kuran, A. 1968. The Mosque in Early Ottoman Architecture. Chicago: The University of Chicago Press.

Mastingah, 2010. Sekitar Perjanjian Giyanti (On the Pact of Giyanti). Yogyakarta: Universitas Islam Negeri Sunan Kalijaga Yogyakarta.

Murti, D. A. 2016. Settlement Patterns Around The Pathok Negoro Mosque Mlangi and Plosokuning Yogyakarta. Yogyakarta: Universitas Gadjah Mada.

Nafisyah, S., \& Rokhman, M. 2016. Masjid Pathok Negoro Sulthoni Sebagai Pusat Akulturasi Budaya 19762000 (Masjid Pathok Negoro Sulthoni as the Center of Cultural Acculturation 1976-2000). Yogyakarta: Universitas Negeri Yogyakarta.

Oğuzoğlu, Y. 2013. 8500 Yıllık Uygarlı̆̆ın İzinden : Bursa Tarihi (From the Trace of 8500-years Civilization: The History of Bursa). Bursa: Bursa Büyükşehir Belediyesi.

Pancaroğlu, O. 1995. Architecture, Landscape, and Patronage in Bursa : The Making of an Ottoman Capital City. Turkish Studies Association Bulletin, Vol. 19, No. 2., 40-55

Pemberton, J. 2003. "Jawa": On the Subject of Java. Yogyakarta: Mata Bangsa.

Prasetyo, J. E. 2016. Masjid Pathok Negoro Plosokuning 1724-2014 : Kajian Sejarah Arsitektur Jawa (Masjid Pathok Negoro Plosokuning 1724-2014 : Historical Analysis on Javanese Architecture). Jakarta: Universitas Islam Negeri Syarif Hidayatullah.

Rahmawati, I. 2014. Arsitektur Masjid Pathok Negoro ditinjau dari Fungsi, Bentuk, Ruang dan Teknik (The Architecture of Masjid Pathok Negoro in terms of Functions, Forms, Spaces, and Techniques). Yogyakarta: Universitas Gadjah Mada. 
Setiabudi, B. 2005. A Study on the History and Development of the Javanese Mosque Part 2 : The Historical Setting and Role of the Javanese Mosque under the Sultanates. Journal of Asian Architecture and Building Engineering (JAABE), 1-8.

Sumardjo, J. 2002. Arkeologi Budaya Indonesia (Archeology of Indonesian Cultures). Yogyakarta: Qalam.

Tjahjono, G. 1989. Cosmos, Center, and Duality in Javanese Architecture Tradition : Symbolic Dimensions of House Shape in Kota Gede and Surrounding. Berkeley: University of California.

Utomo, Y. W. 2015, January 26. Dusun Mlangi : Wisata Religius Islami (The Village of Mlangi : IslamicReligious Tourism). yogyes.com: https://www.yogyes.com/id/yogyakarta-tourismobject/pilgrimage-sites/mlangi/

Wardatun, E. 2001. Perkembangan Masjid Taqwa Wonokromo Bantul 1970-1997 - Tinjauan Sejarah dan Kebudayaan Islam (The Development of asjid Taqwa Wonokromo Bantul 1970-1997 - Analysis on Islamic History and Culture). Yogyakarta: Institut Agama Islam Negeri Sunan Kalijaga Yogyakarta.

Cultural Boards of Yogyakarta \& UGM. 2006. Menjadi Jogja (Become Jogja). Yogyakarta: Panitia HUT ke250 Kota Yogyakarta.

Yuli, N. G. 2015. The Comparison of the Muslim Settlements in Pathok Negoro Area, Yogyakarta, Indonesia. International Research Journal of Engineering and Technology (IRJET), 248-252.

The photographs and drawings of masjid pathok negoros are taken with permission from the personal archive of Hendro Trieddiantoro. 